\title{
Judicialização da política no enfrentamento à Covid-193: \\ um novo padrão decisório do STF?
}

Judicialization of politics in the fight against Covid-19: a new STF decision-making pattern?

\section{Introdução}

A pandemia de Covid-19 trouxe consigo não apenas uma crise sanitária sem precedentes na história do Brasil recente, mas também o agravamento da crise política. E, como de costume, os embates políticos deságuam no Judiciário, promovendo a judicialização da política e das políticas públicas. Partidos de oposição ao governo federal têm utilizado o Supremo Tribunal Federal como um caminho para contestar e derrubar medidas relacionadas à pandemia adotadas pelo presidente da República, Jair Bolsonaro. Tal como acontecia nos anos 1990, no governo de Fernando Henrique Cardoso, a judicialização da política se mostra um importante instrumento político de oposição e de enfrentamento político (VIANNA et al., 1999; CASTRO, 1997; CARVALHO, 2004; OLIVEIRA, 2005).

\footnotetext{
Professora Associada de Ciência Política na Pós-Graduação em Políticas Públicas da Universidade Federal do ABC (UFABC), São Bernardo do Campo, SP, Brasil. E-mail: <vanessa.oliveira@ufabc.edu.br>

2 Professora Associada do Departamento de Ciência Política e do PPG em Políticas Públicas da Universidade Federal do Rio Grande do Sul (UFRGS), Porto Alegre, RS, Brasil. E-mail: <ligiamorimadeira@gmail.com> 3 Para replicação de dados ver: https://doi.org/10.7910/DVN/X4WBSF
} 
Este é o objeto do presente artigo: a judicialização da política no enfrentamento à Covid-19 no Brasil. As perguntas que buscamos responder são: o padrão de judicialização da política verificado na pandemia é novo ou, ao contrário, repete o padrão verificado nos anos 1990 e início dos anos 2000, marcado pelo uso político do Judiciário pelos partidos de oposição? E em relação à questão federativa, ele difere do padrão centralizador das decisões da Corte, apontado por estudos anteriores? Nossa hipótese é a de que verificamos atualmente o mesmo padrão anteriormente registrado, em termos de quem mobiliza o Judiciário, mas com resultados distintos: agora, o presidente mais perde do que ganha no Supremo Tribunal Federal (STF), nos casos de controle de constitucionalidade de atos relacionados ao enfrentamento da pandemia. Conforme os dados demonstram, essa hipótese se confirma, mas, no que diz respeito à questão federativa em um sentido mais amplo, ainda não é possível afirmar a existência de um novo padrão decisório.

Para trabalhar com essas questões, mobilizamos a literatura de judicialização da política e analisamos as Ações Diretas de Inconstitucionalidade (ADIs), as Arguições de Descumprimento de Preceito Fundamental (ADPFs) e as Ações Diretas de Inconstitucionalidade por Omissão (ADOs) ajuizadas no STF entre os meses de março e novembro de 2020. Ao todo, são 101 ADIs, 25 ADPFs e duas ADOs. A análise recorreu ao universo de ações de constitucionalidade interpostas ao STF relacionadas ao coronavírus - foram utilizados como critérios de busca os indexadores "covid" ou "pandemia" ou "coronavírus" ou "Sars-CoV-2". Como nos estudos sobre judicialização da política no Brasil, examinamos quem são os requeridos, os requerentes, os temas contestados quanto à sua constitucionalidade, bem como os resultados alcançados por essas ações.

A análise demonstra que o controle de constitucionalidade foi utilizado como instrumento para a contestação política de uma série de medidas do governo federal na pandemia. Governadores e partidos de oposição judicializaram a política, tal como a literatura verificou para o período dos governos $\mathrm{FHC}$, mas, ao contrário do ocorrido naquele momento, agora o presidente perde mais 
do que ganha no STF nas questões relativas ao enfrentamento à crise sanitária - em especial no julgamento da constitucionalidade das Medidas Provisórias (MPs). Esse resultado se mantém tanto na observação quantitativa das ADIs quanto em sua análise qualitativa, isto é, dos assuntos por ela tratados. A pesquisa, por meio do caminho metodológico apresentado a seguir, mapeou os atores envolvidos na judicialização da política de enfrentamento à Covid-19 no país, os seus questionamentos e os efeitos (alguns temporários) de sua atuação - embora ainda não seja possível conhecer o resultado definitivo desse processo, já que muitas das ADIs aguardam julgamento ${ }^{4}$.

Essa investigação demonstra que, em primeiro lugar, a nossa hipótese se confirma, ou seja, são os partidos de oposição os que mais mobilizaram a Corte durante a pandemia e, além disso, o presidente não foi o principal ganhador, tal como nos anos 1990, naquilo que denominamos por "primeira onda da judicialização". Ao contrário, o presidente mais perdeu do que ganhou no STF nos temas diretamente relacionados às medidas sanitárias voltadas ao enfrentamento da Covid-19, em especial nas MPs. Um segundo achado importante, o qual dialoga com as análises sobre a atuação da Corte em questões de ordem federativa: embora os ministros tenham assegurado o papel de estados e municípios na condução das medidas sanitárias necessárias para o controle da pandemia, inclusive em relação à obrigatoriedade da vacinação, as demais decisões, não relacionadas às medidas sanitárias, não demonstram a alteração do padrão "centralizador" de atuação da Corte, no sentido de que não reforçam o poder dos entes subnacionais, em detrimento do poder do ente federal. Trata-se, portanto, de uma garantia do poder dos níveis subnacionais na condução das medidas de saúde pública, mas ainda não é possível afirmar que

4 O mesmo aconteceu com os estudos sobre judicialização que marcaram aquilo que denominamos por "primeira onda" desse campo. Oliveira (2005), por exemplo, lidou com os casos de contestação ocorridos nos processos de privatização das empresas estatais. Algumas ações só foram encerradas muitos anos depois, como a autora salienta no trabalho. 
houve uma alteração no padrão decisório da Corte num sentido mais amplo, nos vários outros temas que a ela chegaram.

O artigo está estruturado em cinco seções, para além da presente introdução. Na próxima seção, apresentamos e atualizamos o debate teórico sobre judicialização da política no Brasil, que foi significativo no início dos anos 2000, mas perdeu espaço na agenda da Ciência Política nos anos mais recentes - mais voltada para a análise do comportamento da Corte, com menor atenção para seu uso político pelos partidos de oposição. Em seguida, em materiais e métodos apresentamos a metodologia utilizada para a coleta e análise dos dados. Na seção 4, apresentamos os resultados, analisando as ADIs, ADPFs e ADOs, seus perfis e resultados das liminares e dos méritos das ações já julgadas pelo STF. Na quinta seção, discutimos os achados empíricos à luz da literatura apresentada. Concluímos com algumas considerações sobre o tema, apresentando os limites da pesquisa e novas hipóteses a serem exploradas em estudos futuros.

\section{A judicialização da política ontem e hoje}

De acordo com os estudos relacionados, a judicialização da política pode ser entendida como a crescente utilização do sistema de justiça nos casos em que a atuação dos poderes Legislativo e/ ou Executivo é percebida por atores políticos e sociais como falha, omissa ou insatisfatória (COUTO; OLIVEIRA, 2019).

Reconstruindo a história do debate acadêmico sobre a judicialização da política e das políticas públicas no Brasil, pode-se dividi-la em três fases distintas. Em um primeiro momento, nos anos $1990 \mathrm{e}$ na primeira metade dos anos 2000, discutiu-se a judicialização da política por meio de dois conjuntos de trabalhos que desdobravam criticamente a explosão de processos judiciais envolvendo questões próprias do mundo da política. De acordo com os trabalhos do primeiro conjunto, a judicialização da política estava associada com a possibilidade de interferência do Judiciário na política, independentemente dos resultados alcançados pela ativação das Cortes; portanto, a possibilidade de mobilização do Judiciário já significava uma alteração do jogo político, tornando-o um ator político 
relevante. Encontram-se nesse grupo os trabalhos de Vianna e colaboradores (1999) e Castro (1997).

O segundo grupo envolve trabalhos que atentaram para os resultados alcançados pelas decisões judiciais em termos de alteração ou manutenção do status quo. Conforme os seus autores, para compreender o alcance da judicialização era preciso analisar o resultado efetivo da intervenção judicial sobre as políticas e políticas públicas em jogo. Assim, o mero aumento da demanda não era "suficiente para caracterizar uma judicialização da política" (CARVALHO, 2004, p. 122). Seguindo essa linha, Oliveira (2005) investiga o processo de privatizações no Brasil e demonstra que, embora tenha sido muito acionado, as decisões judiciais não alteraram o resultado dos processos de privatização em curso no governo FHC.

Esse debate inicial buscava lidar com um fenômeno novo no Brasil, naquele momento ainda pouco familiar. Os especialistas reconheciam a importância dada ao Judiciário como o órgão responsável pelo controle de constitucionalidade das leis nas democracias contemporâneas e buscavam compreender a magnitude e as consequências políticas do fenômeno (OLIVEIRA; CARVALHO, 2006). Além disso, frente à limitada disponibilidade de dados, concentrados sobretudo no Supremo Tribunal Federal e no controle de constitucionalidade, a atenção se voltava especialmente para a análise das ADIs como principal caminho para se conhecer a interferência do Judiciário em temas próprios do mundo da política.

A "primeira onda" dos estudos sobre a judicialização no Brasil foi central na inclusão do Judiciário nas análises sobre as políticas e as políticas públicas. Embora limitados pela dificuldade do acesso a dados, eles lançaram luz sobre outras possibilidades de análise e atuação do sistema de justiça, dando início a novas análises.

Após essa primeira onda, a ciência política brasileira produziu uma série de trabalhos acerca da judicialização da política focados no impacto das decisões judiciais em diferentes etapas do jogo político. Esses conformaram a "segunda onda" a respeito da judicialização, ocorrida a partir da segunda metade dos anos 2000. 
Os autores da segunda onda trouxeram à tona a importância de se atentar para os diferentes momentos de interferência do Judiciário no jogo político, assim como explicar as causas dessa interferência. Segundo eles, ao contrário do que propunham as análises a partir do resultado das decisões políticas, a interferência do Judiciário se dava não apenas na implementação das políticas, mas, previamente, na própria definição das regras do jogo.

Destacam-se aí os trabalhos de Marchetti (2008) e Marchetti e Cortez (2009), que examinaram a judicialização da competição político-partidária e os efeitos da atuação do Judiciário sobre as regras eleitorais e, desse modo, sobre o resultado da competição eleitoral. Apesar de questionar os estudos focados nos resultados da interferência judicial para as políticas e políticas públicas, Marchetti (2008) analisa decisões do TSE e do STF, apresentando casos em que a atuação judicial efetivamente impactou o resultado da política eleitoral.

Outra pesquisa importante da segunda onda foi a de Taylor (2008), a qual argumentou que os atores políticos se utilizam das Cortes como veto points, buscando alterar o processo de implementação de políticas públicas. Sem necessariamente esperar a vitória no processo judicial, o autor afirma que aqueles que mobilizam a justiça possuem não apenas um, mas quatro objetivos: (i) retardar; (ii) impedir a implementação; (iii) desmerecer a política; (iv) declarar a sua oposição a ela. $\mathrm{O}$ autor avança em relação à primeira onda, afirmando que restringir as análises aos casos que conseguem, de fato, alterar a política é limitar o entendimento sobre a extensão do Judiciário de influenciar a política, o que ocorre mesmo em casos em que não se tem a vitória judicial, mas a mobilização das Cortes altera o contexto no qual os atores políticos jogam.

Nessa mesma linha, Taylor e Da Ros (2008) tentaram compreender padrões de judicialização da política nos governos FHC e Lula, comparativamente, como também as razões das diferenças encontradas no padrão de judicialização nos dois governos. De acordo com os autores, a pergunta que buscam responder é: "[...] sob regras institucionais semelhantes, que fatores contribuem 
para a variação no uso dos tribunais pelos atores políticos, especialmente por membros da oposição?" (TAYLOR; DA ROS, 2008, p. 828). Como encontraram diferentes padrões de uso do Judiciário pela oposição nos dois governos - FHC e Lula -, os especialistas buscam compreender o que explica tais diferenças. Nesse sentido, as diferenças se encontram tanto nos atores que acionam o Judiciário quanto na saliência dos temas e no contexto político em que a judicialização acontece (Ibidem, p. 829). Mesmo utilizando estratégias metodológicas típicas da "primeira onda" de estudos sobre judicialização da política (em especial, as taxas de sucesso em ADIs), avançaram metodologicamente ao observarem os diferentes padrões de judicialização, o que não é feito apenas pela leitura dos resultados das ADIs, mas do que se está questionando, bem como de uma interpretação política disso, encontrando tipos distintos de judicialização - a "judicialização como arbitragem de interesses em conflito" ou a "judicialização como instrumento de governo".

Já a partir dos anos 2010 os trabalhos sobre judicialização entraram na "terceira onda", centrados nos resultados em termos de políticas públicas, com especial atenção para a judicialização da saúde. A interferência do Judiciário nas políticas públicas ensejou uma série agrupada sob o nome de judicialização de políticas públicas, que seria a

crescente utilização do sistema de justiça, não para a resolução de conflitos políticos (politics), mas para o questionamento de falhas ou omissões na produção de políticas públicas (policies) por parte do Executivo, ou inação ou falhas do Legislativo no que tange à produção de normas legais (OLIVEIRA, 2019, p. 18).

Esse conceito se adequa à análise das mais variadas políticas públicas: saúde, educação, habitação, assistência social, entre outras.

Interessante observar que a judicialização da política perde terreno nas pesquisas da ciência política a partir de 2010, sendo encontrados trabalhos sobre o tema mais no campo do direito, com algumas exceções (por exemplo, OLIVEIRA, 2016). No entanto, 
acabam lidando mais com o aspecto jurídico do que com a abordagem política desse processo. A maneira como o Judiciário interfere na política cotidiana, nas decisões do Executivo, do Legislativo ou na competição político-partidária deixa de ser o foco dos estudos sobre as instituições judiciais. Os estudos sobre judicialização das políticas públicas se alastraram, em especial em saúde pública e em direito, ao passo que, no campo da ciência política, vivencia-se recentemente o crescimento de trabalhos sobre o comportamento dos ministros do STF e seus padrões decisórios (OLIVEIRA, 2012; SILVA, 2018; LIMA; GOMES NETO, 2019, entre outros).

Para resgatar esse debate, analisaremos aqui o padrão observado pelos primeiros estudos da judicialização da política, visando compreender se ele se mantém atualmente, especialmente na judicialização ocorrida na pandemia de Covid-19 no Brasil, entre os meses de março e novembro de 2020.

Para tal, precisamos saber: qual era o padrão de judicialização da política nos trabalhos que inauguraram essa discussão? Quem questionava a constitucionalidade das leis e quem ganhava mais no STF?

O trabalho seminal sobre a judicialização da política é o trabalho de Castro (1997). Nele, o autor analisa 1.240 acórdãos (ementas), classificados em 11 diferentes matérias: política fiscal e tributária; política monetária; política de rendas; políticas setoriais; processo eleitoral; entre outras. Demonstrou-se ali que a produção do STF tendia a favorecer mais aos interesses privados do que aos públicos em matérias de política tributária e em questões de direito penal. Nas demais classes processuais, o STF atendeu mais aos interesses públicos (Ibidem).

Outro padrão decisório observado nos estudos sobre judicialização da política está relacionado às categorias mais específicas de quem aciona a justiça. O estudo de Castro (1997) comparava atores públicos e privados. Vianna e colaboradores (1999), por sua vez, analisaram 1.935 ADIs, afirmando haver "uma resistência do Judiciário ao desempenho de papéis que o arrastem a se tornar um personagem central no processo de judicialização da política” (Ibidem, p. 53), uma vez que mais de $50 \%$ das ações ainda aguardavam julgamento 
de mérito. Em prosseguimento a esse estudo, Vianna, Burgos e Salles (2007) também analisaram 3.648 ADIs, no período entre 1988 e 2005 , observando, inclusive, as mudanças de governo. Conforme os autores, 60\% destas estavam relacionadas à matéria de Administração Pública (VIANNA; BURGOS; SALLES, 2007).

Um segundo aspecto que este trabalho demonstrou é que as ADIs deixavam clara a tendência centralizadora das decisões da Corte, a qual tendia a favorecer a União, em detrimento dos interesses defendidos pelos governos estaduais. Esse mesmo padrão foi observado por Oliveira (2009), ao analisar as ADIs que tratavam do conflito federativo entre estados e governo federal. Trata-se de um ponto importante para a presente discussão, pois, como demonstraremos adiante, essa tendência se alterou na judicialização da política na pandemia, uma vez que o presidente mais perde do que ganha, ao contrário do que a literatura vinha mostrando não apenas nas análises da primeira onda da judicialização da política, mas também em estudos mais recentes (CANELLO, 2016).

Em terceiro lugar, merece destaque a questão dos proponentes. Segundo os autores (VIANNA; BURGOS; SALLES, 2007), ficava clara a preponderância de quatro principais postulantes de ADIs: governadores, em primeiro lugar (26\% do total); associações (24,9\%); procuradores (22,2\%); e partidos (19,8\%), por ordem de participação.

Esse padrão se manteve mesmo depois de uma leva de ADIs de governadores e da Procuradoria-Geral da Reública (PGR) contra as constituições estaduais, o que se dá, sobretudo, na primeira metade dos anos 1990 (COSTA; COSTA, 2018). Após essa fase de contestação de dispositivos das constituições estaduais, já no governo FHC, os governadores continuaram como o grupo majoritário com ADIs contra a legislação infraconstitucional. Segundo Costa e Costa (2018), intensificou-se, nesse momento, a participação dos partidos políticos, mas a PGR, chefiada por Geraldo Brindeiro, diminuiu o seu nível de atuação no controle concentrado (COSTA; COSTA, 2018, p. 160).

No governo Lula, foram observadas uma ligeira diminuição na presença de associações e de governadores e uma queda mais 
acentuada da presença dos partidos políticos como postulantes. Por outro lado, o Ministério Público passou a ter um papel mais ativo. Segundo Vianna, Burgos e Salles (2007, p. 47):

[...] verifica-se uma troca de posições da importância relativa dos partidos e dos procuradores. Enquanto a participação dos procuradores sobe de $11,2 \%$ para $35,9 \%$, a dos partidos cai de $28 \%$ para menos de $15 \%$ nesse período [Lula], o que se deve, em grande medida, à queda da presença da esquerda no cenário das Adins.

Importante ressaltar que a participação de partidos nas ADIs apresentava uma variação em relação ao espectro ideológico: 56,6\% das ADIs de partidos eram oriundas de partidos de esquerda, caindo para $14,9 \%$ para partidos de centro e $7,5 \%$ para partidos de direita, sendo o restante procedente de partidos classificados pelos autores como "nanicos". Nessa perspectiva, fica claro que a judicialização era, entre 1988 e 2005, uma estratégia mais adotada pelos partidos de esquerda do que de centro ou direita. Esse quadro muda quando se observa o governo Lula isoladamente, uma vez que era o Partido dos Trabalhadores um dos principais proponentes de ADIs no governo FHC. Obviamente, quando assume o poder, o PT deixa de utilizar a judicialização como estratégia de contestação das ações do governo federal.

Faz-se essencial salientar ainda que os dados de Costa e Costa (2018), os quais abrangem todo o período 1988 - 2017, demonstram que entre 2013 e 2017, intervalo denominado por "fase 5", "os partidos políticos impugnaram principalmente atos do Poder Executivo, especialmente medidas provisórias, o que indica que eles utilizam essa via como uma continuidade dos embates políticos que ocorrem na arena do Congresso Nacional." (Ibidem, p. 166). Esse padrão se repetiu na pandemia, conforme os resultados demonstram.

Por fim, o trabalho de Vianna, Burgos e Salles (2007) confirma a prevalência de ADIs contrárias às normas dos Legislativos estaduais (55\%), seguidas pelas ADIs em contestação ao Legislativo federal 
(16,6\%), em proporção bem menor, e depois refutando o Executivo federal $(13,9 \%)$. Diversamente, na pandemia, as normas atacadas são, principalmente, as MPs do Executivo federal, o que constitui uma diferença relevante em relação ao que os autores observaram no período 1988 - 2005, conforme discutiremos adiante.

Esses são os principais elementos que compõem aquilo que chamamos por um "padrão" da judicialização da política. De maneira sintética, são eles: (i) o fato de as ADIs serem um instrumento dos partidos de oposição (e, em alguns momentos, especialmente partidos de esquerda); (ii) de ser um instrumento bastante utilizado pelos governadores, sobretudo contra as próprias assembleias legislativas estaduais, em questões constitucionais ou mesmo questionando a legislação infraconstitucional; (iii) a tendência centralizadora das decisões da Corte, que demonstrou favorecer a União em detrimento dos interesses defendidos pelos governos estaduais em ações envolvendo conflitos federativos.

Vale ressaltar que a ideia de um padrão não desconsidera a existência de diferentes momentos da judicialização da política, cada qual com suas características em termos de quem aciona a Corte, questionando qual tema ou objeto, conforme o meticuloso trabalho de Costa e Costa (2018) já atestou. Mas eles foram aqui agrupados de modo a permitir uma análise das principais características desse processo nos trabalhos anteriores, a serem comparadas com aquelas verificadas atualmente, na judicialização da política no contexto da pandemia.

\section{Materiais e métodos}

Esta pesquisa se baseia nos métodos quantitativo e qualitativo. $\mathrm{Na}$ frente quantitativa, foram coletadas as ADIs, as ADPFs, além das ADOs ajuizadas no STF entre os meses de março e novembro de 2020. Ao todo, foram 101 ADIs, 25 ADPFs e duas ADOs. Atualizou-se o andamento das ADIs até o dia 2 de março de 2021. Para a coleta das ADIs, ADOs e ADPFs, procedemos à busca pelas seguintes palavras-chave no site do STF: "covid"; "coronavírus"; "Sars-CoV-2"; "pandemia”. 
Primeiramente organizados em planilha Excel, os dados foram trabalhados por meio de estatísticas descritivas, suficientes para a compreensão do nosso objeto de pesquisa. Tal como nos estudos sobre judicialização da política no Brasil, analisamos quem são os requeridos, os requerentes, os temas contestados quanto à sua constitucionalidade e os resultados alcançados por essas ações. Seguiu-se uma análise de conteúdo das ações a partir da classificação por: (i) número da ação; (ii) estado de origem; (iii) data de protocolo; (iv) ministro relator; (v) requerentes; (vi) requeridos; (vii) norma contestada; (viii) esfera de atuação das partes requeridas; (ix) status da decisão no momento da análise; $(x)$ processo apensado/principal; (xi) o ministro da Saúde à época da interposição. Incluímos a categoria ministro da Saúde de maneira a ilustrar que tipos de discussão foram provocados por cada conjuntura de atuação do Ministério da Saúde (MS)na gestão da pandemia no país.

Posteriormente, realizamos uma análise qualitativa de redes para identificar e visualizar as relações tanto entre as Ações Diretas de Inconstitucionalidade (conteúdo da lide) quanto entre requerentes e as ADIs que se repetem, pois tratam do ataque a uma mesma norma. A análise de redes permitiu mapear e perceber as disputas de atores e seus interesses em torno de um determinado tema de política (representado por meio do questionamento de uma norma atacada), demonstrando as diferentes interações entre os atores políticos em disputa no STF. Os dados das redes, dispostos em matrizes, foram representados em grafos, produzidos por meio dos softwares NetDraw e UCINET, que nos indicam conjuntos de nós - as ADIs, as normas atacadas e os requerentes, bem como os laços indicando a presença de relacionamentos e vínculos entre os nós.

Os métodos utilizados se justificam, pois a estatística descritiva, comumente utilizada para a análise de ADIs, permite-nos compreender cenários comparativos de comportamento judicial no tempo. Além disso, a análise qualitativa das redes se mostrou adequada para a compreensão dos temas tratados pelas ADIs e as proximidades temáticas entre as diferentes ações. Esses caminhos 
metodológicos nos permitiram chegar aos resultados, apresentados a seguir.

\section{Resultados}

\section{As ADIs, seus atores e resultados}

O Supremo Tribunal Federal (STF) é o guardião da Constituição, dispondo de instrumentos para controle do questionamento da constitucionalidade dos atos governamentais, entre eles as Ações Diretas de Inconstitucionalidade (ADIs), que podem ser propostas seguindo o art. 103, incisos I a IX, da CF/1988, pelas seguintes instâncias: (i) presidente da República; (ii) Mesa do Senado Federal; (iii) Mesa da Câmara dos Deputados; (iv) Mesa da Assembleia Legislativa ou Câmara Legislativa do Distrito Federal; $(v)$ governador de Estado ou do Distrito Federal; (vi) procurador-geral da República; (vii) Conselho Federal da Ordem dos Advogados do Brasil; (viii) partido político com representação no Congresso Nacional; (ix) confederação sindical ou entidade de classe de âmbito nacional.

De modo a conhecer a atuação do STF e a judicialização no tribunal em torno do combate ao coronavírus, analisamos 128 ações (101 ADIs, 25 ADPFs e 2 ADOs) iniciadas entre os meses de março e novembro de 2020. A análise utilizou o universo de ações de constitucionalidade interpostas ao STF relacionadas ao coronavírus. Utilizamos como critérios de busca no sítio eletrônico do tribunal (www.stf.jus.br) os indexadores "covid" ou "pandemia" ou "coronavírus" ou "Sars-CoV-2".

O cenário da judicialização durante a pandemia indica alguns aspectos interessantes. Em primeiro lugar, salta aos olhos o questionamento de atos normativos emitidos pelo presidente da República. Ele foi demandado em mais de $60 \%$ das ADIs, seguido pelos governadores, em cerca de 35\% das ações.

Das 101 ADIs ajuizadas, 66 são originárias do Distrito Federal, dado que o presidente da República é o principal requerido, seja sozinho (37 ADIs), seja junto ao Congresso Nacional (22 ADIs); ao CNJ (duas ADIs); e ao Congresso Nacional e ao TSE (uma ADI). O 
Congresso Nacional, por meio das Mesas da Câmara de Deputados e do Senado, é requerido também em uma ADI. O Banco Central do Brasil (Bacen) e o Conselho Monetário Nacional (CMN) são igualmente requisitados em uma ADI, e o Conselho Nacional de Justiça (CNJ) em outra. São 27 ADIs requerendo governadores e assembleias legislativas estaduais e mais oito, cujas partes são as Assembleias Legislativas, originárias do Rio de Janeiro (6 ADIs); Mato Grosso (5); Paraíba (5); Maranhão (4); Santa Catarina (3); Rondônia (2); Roraima (2); e uma Ação Direta nos Estados do Paraná, do Ceará, do Piauí, do Rio Grande do Norte, de Pernambuco, do Pará, do Espírito Santo, do Amazonas e da Bahia.

Quanto aos requerentes, pelo art. 103, incisos I a IX, da CF/1988, o gráfico a seguir demonstra o protagonismo dos partidos políticos em 41 ADIs, seguidos por federações e confederações sindicais (27) e por entidades de classe de âmbito nacional (21). O procurador-geral da República ingressou com 6 ADIs, os governadores de estado com 4, o presidente da República com uma e o Conselho Federal da Ordem dos Advogados do Brasil com outra.

Gráfico 1 - Tipos de requerentes: ADIs sobre coronavírus de março a novembro de 2020

Partido político

Federação/Confederação sindical

Entidade de classe nacional

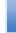

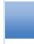

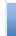

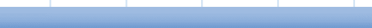

27

\begin{abstract}
Entidade de classe nacional
\end{abstract}
PGR

Governador
Presidente da República
Conselho Federal OAB

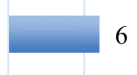

$$
\begin{array}{lllll}
0 & 5 & 10 & 15 & 20
\end{array}
$$

21

\section{7}


Entre os partidos, o PDT ajuizou sete ações; a Rede Sustentabilidade, seis; o PSB seis isoladamente e uma com outros partidos; PCdoB, três; PSOL, duas; PT, três de modo isolado e, em conjunto com o PCdoB e o PSOL, mais duas; PCdoB, três; PSOL e Cidadania, duas ações cada um; e os partidos PTB, PP, PSDB, PV, Pros, Podemos, Solidariedade e Avante, uma ADI cada 5 .

Das 101 ações, 15 foram interpostas em março, 26 em abril, 22 em maio, 14 em junho, 12 em julho, oito em agosto e quatro em outubro. Verificamos que cerca de um terço das ADIs foram ajuizadas ainda durante a gestão de Luiz Henrique Mandetta no Ministério da Saúde (31). Na gestão de Nelson Teich, mais 24 ADIs, e durante o mandato de Eduardo Pazuello, até então, interpostas 46 ações.

Em relação ao tipo de norma, das 101 ADIs ajuizadas sob o tema coronavírus, 65 (64\%) atacam normas federais e 36 (35\%), normas estaduais. Das 65 contra as normas federais, 36 investem contra 10 MPs propostas pelo presidente da República.

Como muitas ADIs insurgem-se contra uma mesma norma, o grafo a seguir (Figura 1) apresenta as redes formadas por essas ações, geralmente reunidas em torno da discussão sobre a (in) constitucionalidade de medidas provisórias editadas por Bolsonaro no curso da pandemia. Entre elas, verifica-se um conjunto de dez ADIs questionando a constitucionalidade da MP n. 927, que tratava da flexibilização de regras de acordo individual de trabalho. Essa medida provisória não foi convertida em lei, logo todas as ações diretas de inconstitucionalidade perderam o objeto de ação e foram extintas e já transitadas em julgado. Como mostraremos, houve deferimento de liminar em desfavor da União.

Outra rede ataca a Medida Provisória n. 966, que dispõe sobre a responsabilização dos agentes públicos pela prática de atos relacionados com as medidas de enfrentamento à pandemia, com liminar deferida em parte ainda pendente de decisão final, impondo, assim, perdas à União.

5 Para a lista de ADIs ajuizadas por federações e confederações sindicais e por entidades de classe de âmbito nacional, conferir o banco de dados disponibilizado. 
A rede em torno da MP n. 954 engloba cinco ADIs, que questionam o compartilhamento de dados telefônicos com o Instituto Brasileiro de Geografia e Estatística (IBGE) para suporte a informações durante a pandemia. Também houve liminar deferida nessa ação, interpondo perdas à União e posteriores extinção e trânsito em julgado das ações.

Embora formadas por um número menor de ações, outras redes de ADIs estão formadas rebatendo medidas provisórias editadas pelo presidente Jair Bolsonaro ao longo do ano de 2020. Destaca-se também uma rede formada em torno da Lei Complementar n. 173/2020, que prevê ajuda financeira a estados, a municípios e ao Distrito Federal por meio do Programa Federativo de Enfrentamento à Covid-19. A maior parte dessas ações já transitou em julgado, tendo havido deferimento de medida cautelar em proveito da União, estados e municípios.

As duas últimas ADIs interpostas foram referentes à vacinação e refutaram a Lei n. 13.979, de 6 de fevereiro de 2020, quanto à possibilidade de realização compulsória de vacinação e outras medidas profiláticas. Também se discutiu a requisição administrativa de bens e serviços por gestores locais no combate ao coronavírus. Essas ações foram julgadas em 17/12/2020, e o STF autorizou, por dez votos a um, que todos os entes da federação (governo federal, estados e municípios) podem adotar medidas restritivas para quem se recusar à vacina contra a Covid-19. A vacinação obrigatória não significa a vacinação forçada, mas uma medida necessária para a saúde coletiva. Em relação à possibilidade de requisição de bens e serviços, o STF se posicionou pela constitucionalidade da lei. Ambos os casos impuseram perda de poder de coordenação à União, com estados e municípios garantindo a sua autonomia. 
Figura 1 - Grafo das relações entre as ADls e as normas atacadas

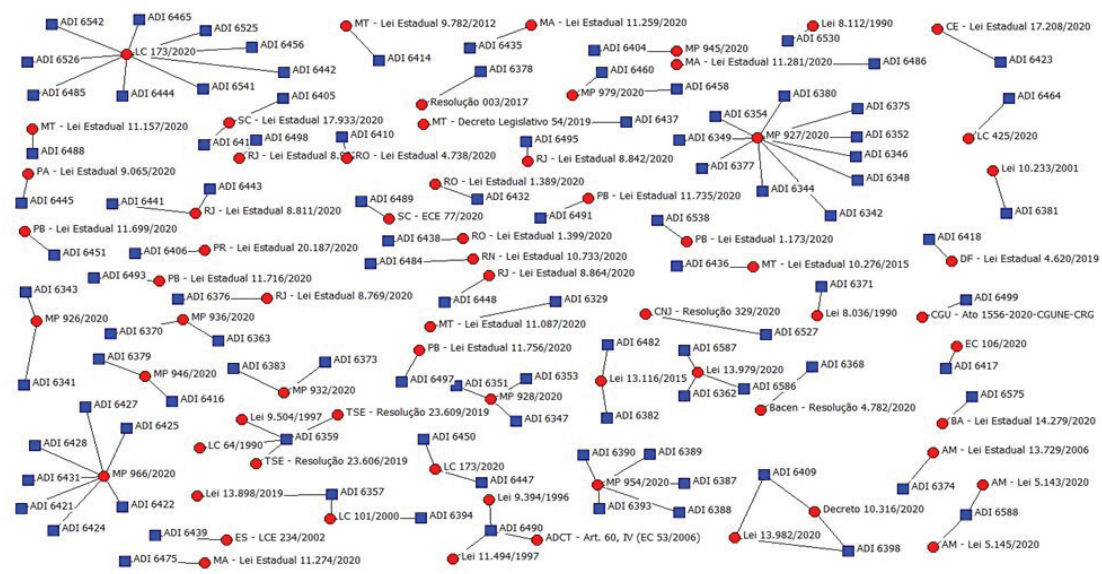

Fonte: elaborada pelas autoras com os softwares NetDraw e UCINET, a partir dos dados de ADIs sobre coronavírus no STF.

Apesar de disperso, o grafo permite visualizar as redes de ações atacando uma única norma, o que prepondera nas ADIs diretamente relacionadas ao combate à pandemia, como é o caso das medidas provisórias e das normas federais que tratam de responsabilidade fiscal, do Programa Federativo de Enfrentamento à Covid-19 e da requisição de bens e serviços por entes locais ${ }^{6}$.

As principais redes estão formadas em torno do questionamento das medidas provisórias e da Lei Complementar n. 173/2020, reunindo tanto confederações sindicais quanto entidades de classe e partidos políticos. Nesse caso preponderam partidos de esquerda e centro-esquerda, ou seja, aqueles de oposição ao governo Bolsonaro. Esses requerentes também estão envolvidos com o questionamento das MPs n. 926, 966, 945, 980.

Ao final do período analisado, os referidos partidos indagam acerca da possibilidade de vacinação compulsória contra o coronavírus. O PDT aposta nessa possibilidade, e o PTB alega a inconstitucionalidade da vacinação compulsória.

6 Conferir anexo com as MPs e suas descrições. 
Enquanto os partidos de esquerda e centro-esquerda atuam em torno das mesmas normas, alguns partidos de direita se destacam pela preocupação isolada com determinados temas - por exemplo, o PP questiona as regras eleitorais e a definição de calendário, domicílio e registro de candidaturas. O STF não interferiu na questão política envolvida no calendário e nas regras eleitorais, julgando improcedente essa ação.

Governadores têm na objeção às normas que regem o Fundo de Manutenção e Desenvolvimento da Educação Básica e de Valorização da Educação (Fundeb) a maioria das suas ADIs, ainda aguardando julgamento. Já o presidente da República está questionando a Lei de Diretrizes Orçamentárias (LDO) e a Lei de Responsabilidade Fiscal (LRF ${ }^{7}$. As normas federais objeto das ADIs têm em seu conteúdo principalmente questões orçamentárias e de responsabilidade fiscal, liberação de recursos e auxílios e as eleições municipais 2020.

Já as normas estaduais objeto de ADIs versam sobre a proibição de interrupção de serviços essenciais, vedação à suspensão e cancelamento de planos de saúde, descontos em mensalidades da educação privada e verbas indenizatórias de serviços públicos. A maioria dessas ações aguarda julgamento, tendo sido julgadas poucas medidas cautelares. Quanto aos objetos de questionamento por parte do procurador-geral da República, destacam-se normas de organização judiciária, que definem planos de carreira de órgãos do sistema de justiça e de servidores militares, bem como subsídios a deputados estaduais.

Outras ADIs promovidas contra normas estaduais concentram-se nas leis que reduzem mensalidades escolares, propostas pelo Confenen, e suspendem cobrança ou impedem cortes em serviços essenciais como luz elétrica, e são em sua maioria de propositura da Abradee, ABCON e Consif. Também contra as normas estaduais, a União Nacional das Instituições de Autogestão em Saúde (Unidas), juntamente com a Confederação Nacional das Empresas de Seguros

7 O quadro, contendo todas as normas federais questionadas por ADIs, está em anexo. 
Gerais, Previdência Privada e Vida, Saúde Suplementar e Capitalização (CNSEG), tem protagonismo, questionando legislações estaduais que vedam a suspensão e o cancelamento de planos de saúde por falta de pagamento e que proíbem operadoras de planos de saúde recusarem a prestação de serviços a pessoas suspeitas ou contaminadas pela Covid-19 em razão de plano de carência contratual. Grande parte dessas ações aguarda julgamento ${ }^{8}$.

Em relação ao status das decisões no momento da análise, até março de 2021 apenas doze ações contavam com julgamento de mérito (cinco delas já com trânsito em julgado). Do universo de 36 ações já transitadas em julgado, a maioria foi sem decisão de mérito (com processos extintos, julgados prejudicados ou negados seguimento). Além disso, havia mais um processo extinto, ainda sem trânsito em julgado. A maioria das ações permanecia sem decisão final (57 ADIs).

Com relação ao julgamento das liminares, 40 ainda aguardam julgamento, 32 foram deferidas, seis indeferidas, 23 não foram julgadas, foram prejudicadas ou tiveram o processo extinto. A tabela a seguir agrupa o status das decisões liminares pelas partes requeridas. Entre as 31 liminares deferidas, $84 \%$ abrangem ADIs contra o presidente da República (27 ADIs), 16\% (cinco ADIs) deferidas em ADIs contra governos estaduais (governadores e assembleias legislativas). As liminares indeferidas também se concentram nas ADIs contra a Presidência da República (cinco das seis indeferidas, isto é, 83\%). Por outro lado, $30 \%$ das ADIs contra a Presidência (12 ADIs) ainda aguardam julgamento, ao passo que as ADIs confrontando os governos estaduais ainda esperam o julgamento em $63 \%$ dos casos (25 ADIs).

8 Em anexo, o quadro com todas as normas estaduais objeto de ADI. 
Tabela 1 - Status dos pedidos liminares em ADIs por requeridos

\begin{tabular}{ccccc}
\hline Requerido & Presidente & $\begin{array}{c}\text { Governadores } \\
\text { Assembleias Legislativas }\end{array}$ & Outros & Total \\
\hline Deferida ou deferida em parte & $27(84 \%)$ & $5(16 \%)$ & 0 & $32(100 \%)$ \\
\hline Indeferida & $5(83 \%)$ & $1(17 \%)$ & 0 & $6(100 \%)$ \\
\hline Aguardando julgamento & $12(30 \%)$ & $25(63 \%)$ & $3(7 \%)$ & $40(100 \%)$ \\
\hline Não julgada, prejudicada ou extinta & $18(79 \%)$ & $4(17 \%)$ & $1(4 \%)$ & $23(100 \%)$ \\
\hline Total & $62(61 \%)$ & $35(35 \%)$ & $4(4 \%)$ & $101(100 \%)$ \\
\hline
\end{tabular}

Fonte: elaborada pelas autoras, a partir dos dados ADIs coronavírus no STF.

A Tabela 2 agrupa o status das decisões liminares pelas partes requerentes. Nesse contexto, $89 \%$ das ADIs tiveram como requerente entidades de classe, partidos políticos ou federações/confederações sindicais. Portanto, a grande maioria das liminares deferidas (97\%) ou indeferidas (100\%) foi por eles iniciada, assim como aquelas que aguardam julgamento ou não foram julgadas (53 ADIs, cerca de $52 \%$ do total).

Tabela 2 - Status dos pedidos liminares em ADIs por requerentes

\begin{tabular}{ccccc}
\hline Requerente & $\begin{array}{c}\text { Entidades de classe, } \\
\text { partidos ou sindicatos }\end{array}$ & Presidente e PGR & $\begin{array}{c}\text { Governadores e } \\
\text { Assembleias Legislativas }\end{array}$ & Total \\
\hline Deferida ou deferida em parte & $31(97 \%)$ & $1(3 \%)$ & 0 & $32(100 \%)$ \\
\hline Indeferida & $6(100 \%)$ & 0 & 0 & $6(100 \%)$ \\
\hline Aguardando julgamento & $33(83 \%)$ & $4(10 \%)$ & $3(7 \%)$ & $40(100 \%)$ \\
\hline Não julgada, prejudicada ou extinta & $20(87 \%)$ & $2(9 \%)$ & $1(4 \%)$ & $23(100 \%)$ \\
\hline Total & $90(89 \%)$ & $7(7 \%)$ & $4(4 \%)$ & $101(100 \%)$ \\
\hline
\end{tabular}

Fonte: elaborada pelas autoras a partir dos dados ADIs sobre coronavírus no STF.

Sintetizando os dados apresentados até aqui, trata-se de uma judicialização prioritariamente contra medidas provisórias e, em menor medida, leis estaduais e leis federais, promovida por partidos de espectro ideológico de oposição ao governo, e por confederações 
sindicais e entidades de classe. O padrão requerente-requerido corresponde a "todos" versus Bolsonaro na maioria dos casos (61\% do total das ADIs). Em menor medida, questionamentos de constitucionalidade contrários a normas estaduais ( $35 \%$ dos casos), com casos de representantes de setores atividades econômicas versus leis estaduais que suspendem pagamentos (serviços essenciais, planos de saúde, descontos mensalidades); Bolsonaro versus regras fiscais e PGR versus carreiras estaduais. Todavia, a maioria das ADIs que contestam normas estaduais continua aguardando julgamento (63\% delas). Apenas 16\% foram deferidas, ou deferidas em parte, número que sobe para $84 \%$ nas liminares que têm como requerido o presidente da República.

Apesar desse padrão, quando olhamos para as redes estabelecidas entre as ADIs, tendo como foco o conteúdo das ações, verificamos que a resposta rápida do STF se concentra em poucos casos, em ADIs que se repetem em razão da temática.

É possível fazer dois tipos de análise das decisões proferidas pelo STF: uma primeira, considerando que o número de liminares concedidas revela a preponderância de ações julgadas contra o presidente da República em detrimento de outros entes; outra possibilidade de análise, agora não mais de contagem de decisões liminares, mas em relação ao tipo de norma atacada e seu desfecho, leva em conta as ações conexas/preventas, visíveis pelo agrupamento em redes no grafo.

O grafo a seguir permite visualizar pelo menos dois grandes conjuntos de ações: o primeiro, centrado na ADI n. 6444 - que discute a Lei de Responsabilidade Fiscal (LC n. 101, de 2000) e a Lei de Diretrizes Orçamentárias (Lei n. 13.898, de 2019) - e na ADI n. 6447, que trata do Programa Federativo de Enfrentamento a Covid-19 (LC n. 173, de 2020), estrutura a relação entre as diferentes ações $(6357,6394,6442,6450,6456,6465,6485,6525,6526$, 6541 e 6542). O segundo conjunto estabelece o vínculo entre a ADI n. 6342 e as outras ações que questionam a constitucionalidade da MP n. 927, que dispõe sobre medidas trabalhistas para preservação do emprego e renda durante a pandemia; e a ADI n. 6343, que ataca 
a MP n. 926, que dispõe sobre as medidas de enfrentamento do coronavírus. A associação envolve várias ações (6348, 6349, 6352, $6354,6377,6380,6375,6344,6346)$. Além desses dois conjuntos com vínculo entre um número elevado de $\mathrm{ADIs}$, há outro em torno da ADI n. 6343, agregando mais cinco ADIs (6344, 6348, 6349, 6346 e 6352). Os demais conjuntos relacionam entre duas a três ações.

Figura 2 - Grafo das relações entre as ADls

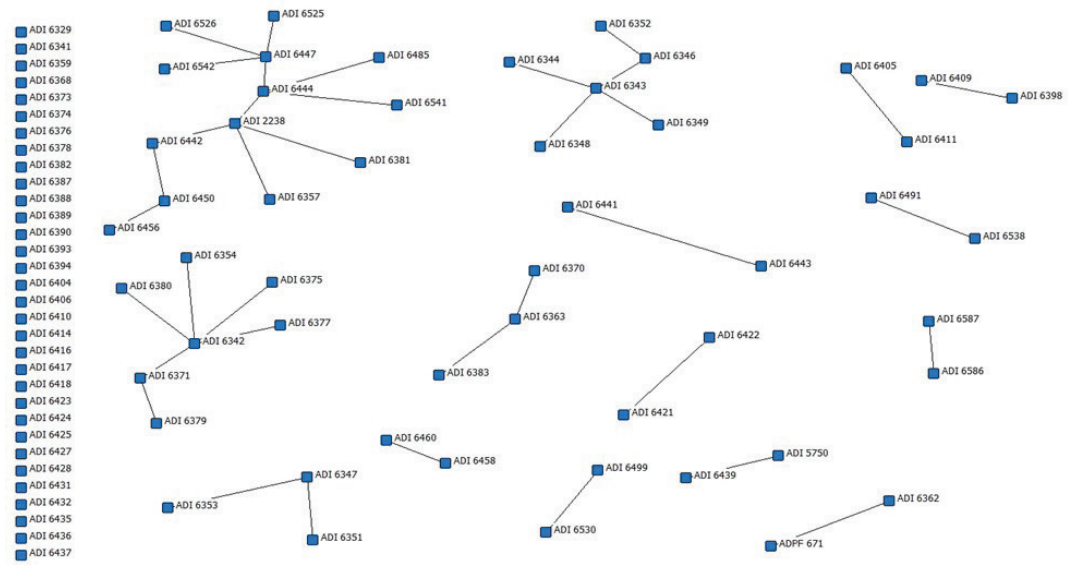

Fonte: elaborada pelas autoras com o software NetDraw e UCINET, a partir dos dados ADIs sobre coronavírus no STF.

O cenário de constrição do presidente da República fica mais evidente ao diferenciarmos os tipos de normas federais (cf. quadros em Anexos).

Analisando as MPs atacadas (Quadro 1 em Anexos), temos aí o maior número de liminares deferidas e também de ações já transitadas em julgado. Confirma-se o argumento de que há preponderância e celeridade no julgamento dessas normas. Das dez medidas provisórias objeto de discussão de constitucionalidade por meio de 36 ADIs, Bolsonaro teve perdas impostas em relação a pelo menos seis delas (MPs n. 926, 927, 928, 954, 966 e 979). Em relação a três medidas provisórias, houve ganho do presidente da República (MPs n. 946, 932 e 936). As perdas do presidente da República não 
implicam, todavia, em ganho dos entes subnacionais, que efetivamente tiveram vitórias apenas com a liminar deferida em relação à MP n. 926, que respaldou as medidas de combate à pandemia tomadas por governadores e prefeitos.

Se é possível verificar tamanha interferência nas MPs, o controle sobre outros tipos de normas federais não é muito incisivo quando analisamos as temáticas/normas confrontadas. Aqui (Quadro 2 em Anexos) temos poucas liminares julgadas, algumas sentenças improcedentes e vários processos aguardando julgamento. Do ponto de vista do embate federativo, presente em cinco normas federais questionadas, estados e municípios ganham em pelo menos duas (nas ADIs da vacinação e da requisição de bens; e no Programa Federativo de Enfrentamento à Covid-19); a União ganha em outras duas (impedimento a liberação de recursos do FGTS a municípios em calamidade pública; e proibição de cobrança por instalação de infraestrutura de comunicação em estados e municípios); e União, estados e municípios compartilham ganhos em relação à Lei de Responsabilidade Fiscal e a LDO.

Já no que se refere às ADIs contra normas estaduais, o quadro oferecido apresentado na análise quantitativa (contagem de decisões liminares) se mantém em uma análise por temática (Quadro $3 \mathrm{em}$ Anexos): a maioria das ações aguarda julgamento, com poucas liminares julgadas e menos ainda deferidas. Considerando que o bloqueio de tais normas pela concessão de liminares não tem sido frequente, pode-se lançar a hipótese de que o STF tem permitido aos entes estaduais maior protagonismo na reação à pandemia. Por outro lado, os dados explicitam a preponderância da constrição do presidente da República em detrimento dos outros entes.

Além disso, se vamos considerar as ações em que efetivamente o STF se posicionou, em sede liminar ou julgando a procedência, restamos com 10 normas ou conjunto de normas em um universo de 101 ADIs em que houve deferimento ou deferimento em parte de liminar: em relação à Lei Complementar n. 173/2020, em relação à Lei Complementar n. 101/2000 e a LDO, ambas tratando de orçamento; em relação a quatro leis estaduais. 


\section{ADPFs e ADOs, seus atores e resultados}

A Arguição de Descumprimento de Preceito Fundamental (ADPF) tem previsão no artigo 102, $₫ 1^{\circ}$, da Constituição Federal de 1988, servindo para atacar casos de desrespeito aos preceitos fundamentais da Constituição, abrangendo atos normativos ou não normativos. Já a Ação Direta de Inconstitucionalidade por Omissão (ADO) busca dar efetividade à norma constitucional objeto de omissão de qualquer dos Poderes ou de órgão administrativo, estando prevista no art. 103, $\$ 2^{\circ}$, da Constituição Federal de 1988.

As ADPFs interpostas sobre a pandemia seguem o padrão das ADIs tanto em relação aos entes requerentes quanto aos requeridos. As ações foram propostas: por partidos políticos (10); por federações e confederações (5); por entidades de classe (4); pelo presidente da República (2); pelo Conselho Federal da OAB (2), atacando principalmente o presidente da República (em sete sozinho e em quatro junto com seus ministros); pelos governadores e prefeitos (3); pelo Congresso Nacional (2); pela União e estados (2); ou por prefeitos (2). Outras ações voltaram-se à União, ao Inep/MEC, àFunai, aos tribunais de justiça dos estados e a uma Câmara Municipal. Trata-se novamente de uma judicialização federal (16 ações) contra poucas ações envolvendo estados (4) e municípios (3). Duas ADPFs envolviam todos os níveis da federação ou conjuntamente as esferas federal e estadual.

Ao longo do ano (março a novembro), contabilizaram-se 25 ações, sendo destas 21 oriundas do Distrito Federal e quatro dos Estados da Bahia (2) e Minas Gerais (2). As ações são todas do primeiro semestre de 2020, revelando um número mais alto nos meses de março (7) e abril (5), com queda em maio (2) e retomada em junho (5) e julho (6).

Quanto aos temas, residem ainda importantes batalhas federativas, a exemplo dos questionamentos do presidente da República sobre a restrição do transporte no âmbito dos estados e municípios (ADPF n. 665), estando a liminar não julgada e ainda aguardando 
a decisão final' ${ }^{9}$; acerca da imposição de fechamento de fronteiras e vias públicas por decretos estaduais e municipais (ADPF n. 675), cuja ação não foi conhecida; a respeito do estabelecimento de medidas restritivas por estados e municípios para o enfrentamento à pandemia da Covid-19, vedando a atividade de locação de veículos automotores, o seguimento foi negado. Chamam atenção duas ações (ADPF n. 701 e 703) interpostas contra autoridades estaduais e municipais por parte da Associação Nacional de Juristas Evangélicos (Anajure) contra tanto a suspensão de atividades religiosas por meio presencial em igrejas, templos ou locais públicos, quanto a determinação de toque de recolher durante o período noturno, inviabilizando o deslocamento da população e, especialmente, dos ministros religiosos, ambas sob alegação de ferimento à liberdade de locomoção, à liberdade religiosa e à laicidade estatal. A primeira ação aguarda julgamento e a segunda teve seguimento negado. Verifica-se que, nesses casos, o não posicionamento do STF tem resguardado a atuação de governos subnacionais e a validade das suas leis de combate à pandemia.

As perdas impostas à Presidência da República também são exemplificadas por várias ADPFs, iniciando-se pela 672, que trata das ações e omissões do Poder Público Federal, especialmente da Presidência da República e do Ministério da Economia, no âmbito da condução de políticas públicas emergenciais nas áreas da saúde e da economia, que já transitou em julgado, com liminar e sentença parcialmente favorável.

As ADPFs n. 668 e 669 questionaram a constitucionalidade da veiculação e dos gastos do erário com a propaganda da Presidência da República intitulada "O Brasil não pode parar", cuja liminar foi deferida e a ação perdeu o objeto pela desistência da veiculação.

As ADPFs n. 676, 691 e 692 contestaram as falhas na divulgação dos dados e na metodologia de apuração do número de infectados, provocadas pelo baixo número de testagens, subnotificação, adoção de medidas de saúde pública precárias e descoladas da realidade,

9 As ADPFs a ADOs tiveram o seu andamento atualizado até dezembro de 2020. 
bem como pela divulgação de informações sem embasamento científico, incluindo a promoção e o incentivo ao uso de medicamentos sem eficácia comprovada e com potencial de gerar efeitos colaterais graves à saúde. Essas ações tiveram liminares deferidas e seguimento negado, dado o recuo do governo federal.

O embate relativo ao uso da hidroxicloroquina também foi objeto de ADPF (n. 707), ainda sem julgamento, com o questionamento de ato do Poder Público Federal, especialmente da Presidência da República e do Ministério da Saúde, sobre o manuseio de medicamentos precoces em pacientes com diagnóstico da Covid-19 e de qualquer protocolo ou documento em que se recomende o uso no âmbito da condução de políticas públicas emergenciais nas áreas da saúde para tratamento de pacientes infectados pelo coronavírus.

Os questionamentos (ADPFs n. 714, 715 e 718) trataram dos vetos presidenciais à obrigatoriedade do uso de máscaras de proteção individual para circulação em espaços públicos e privados acessíveis ao público, em vias públicas e em transportes públicos, acerca tanto da adoção de medidas de assepsia de locais de acesso público, inclusive transportes públicos, quanto da disponibilização de produtos saneantes aos usuários durante a vigência das medidas para enfrentamento da emergência de saúde pública de importância internacional decorrente da pandemia da Covid-19, tendo liminares parcialmente deferidas. A liminar restabeleceu a obrigatoriedade do uso de máscaras.

A omissão e as falhas com que grupos vulneráveis vêm sendo tratados na pandemia incluem ações sobre povos indígenas (ADPF n. 709) e populações prisionais (ADPF n. 684). A primeira teve tutela deferida para que o governo federal fizesse complementação do Plano de Barreiras Sanitárias e extensão do Subsistema de Saúde Indígena aos povos indígenas aldeados residentes em terras não homologadas, com posterior indeferimento à homologação de uma segunda versão do Plano Geral para Enfrentamento e Monitoramento da Covid-19 para Povos Indígenas apresentado pelo governo. Já a segunda restava sem julgamento liminar e final. 
Temas de educação envolvendo a pandemia foram também objeto da ADPF n. 673, que questionou a realização do Enem; e das ADPFs n. 713 e 720, que discutiram os descontos em mensalidades escolares garantidos por atos administrativos e decisões judiciais não transitadas em julgado.

Os resultados até agora dessas ADPFs indicam quase metade das ações com liminares deferidas (12), sendo que oito alcançaram decisões finais: quatro ações obtiveram negado seguimento, duas ações foram extintas por perda de objeto, uma não foi conhecida e outra confirmou resultado final parcialmente procedente. Outra ação teve o seu cabimento provido em agravo regimental.

A análise da concessão de liminares aponta o predomínio de deferimento de tutelas contra a Presidência da República (73\%), sendo que apenas $17 \%$ das ações contra governos estaduais tiveram liminares deferidas. O cenário de julgamento liminar das ADPFs repete os achados em relação às ADIs. Também se reproduz o quadro de ações aguardando julgamento terem os governos estaduais como requerentes (83\%).

Por fim, a judicialização da Covid-19 utilizando-se de Ação de Inconstitucionalidade por Omissão (ADO) é bem menos expressiva. Foram interpostas duas ADOs sobre coronavírus, uma em março e outra em abril. O requerente da primeira foi a Rede Sustentabilidade contra o presidente da República e o Congresso Nacional, versando sobre a suposta omissão inconstitucional e a consequente mora legislativa dessas autoridades, por não concretizarem o comando constitucional contido nos arts. $1^{\circ}$, III, $3^{\circ}$, III, 6 $6^{\circ}$ caput, e art. 170 da CF/1988, no art. 11,. item 1, do Pacto Internacional dos Direitos Econômicos, Sociais e Culturais (Decreto n. 591, de 1992) e no art. 12, do Protocolo Adicional à Convenção Americana sobre Direitos Humanos em Matéria de Direitos Econômicos, Sociais e Culturais (Decreto n. 3321, de 1999), em especial durante a pandemia da Covid-19. Essa ADO teve negado seguimento e já transitou em julgado.

A segunda, interposta pelo partido Democratas e pela Frente Nacional de Prefeitos (FNP) contra o Congresso Nacional, a 
Presidência da República e o CFOAB, reivindica a declaração da mora e inércia legislativa dos requeridos na regulamentação da previsão constitucional inserida nos incisos I a IV do $\$ 4^{\circ}$ do art. 101 do Ato das Disposições Constitucionais Transitórias, que prevê expressamente no prazo de 6 (seis) meses a instituição de linha de crédito especial para o pagamento de precatórios em regime especial em favor dos entes federativos endividados. Esta ADO ainda restava sem julgamento na conclusão da presente análise.

\section{Discussão: um novo padrão de judicialização da política?}

A literatura afirma que emergências requerem delegação passiva de poderes para o Executivo, o qual constitui o único ramo do governo com informação, poder de decisão e velocidade para responder a crises. Ginsburg e Versteeg (2020) avaliam, a partir de um survey global, as bases legais das respostas à pandemia, investigando se o Judiciário tem atuado como um mecanismo de contenção do Executivo, tendo em vista que os constrangimentos constitucionais de check and balances tendem a ser minorados durante crises, em função de uma delegação de poderes que concentra recursos e flexibilidade no Executivo nestes cenários (Ibidem, p. 5).

Os autores demonstraram que as Cortes desempenharam um papel significativo de constrangimento das ações dos Executivos nacionais, atuando como importante instrumento de checks and balances mundo afora. As bases para as intervenções judiciais são de quatro ordens para as Cortes: têm escrutinado se os procedimentos seguidos contam com amparo legal; têm se engajado na revisão de direitos substantivos, considerando que as restrições de direitos são necessárias, mas devem ser proporcionais e igualmente aplicadas; têm demandado que executivos ajam, especialmente em contextos onde os Executivos nacionais estão falhando em responder adequadamente à pandemia; por fim, têm definido sobre o adiamento de eleições, garantindo que essas decisões não sejam baseadas em fundamentos políticos (GINSBURG; VERSTEEG, 2020, p. 6).

$\mathrm{O}$ caso brasileiro demonstra que são robustos os mecanismos de check and balances durante a crise de saúde, junto com metade 
dos países investigados pelos autores em que as Cortes monitoram o Executivo. O próprio envolvimento das Cortes nas respostas à pandemia é um indicativo claro de que o poder Executivo não está totalmente sem limites, estando no mínimo forçado ao diálogo com o Judiciário.

Em se tratando especificamente do STF, como este foi mobilizado e atuou nos casos apresentados à Corte durante a crise instaurada pela Covid-19? O que os dados apresentados anteriormente nos revelam sobre a judicialização da política na pandemia?

Em trabalho sobre a judicialização da política em tempos de pandemia, Fabiana Luci de Oliveira (2020) sustenta a tese de que o "Supremo Tribunal Federal (STF) tem se mostrado ativo no controle da constitucionalidade dos atos do presidente Jair Bolsonaro, relativos à pandemia de Covid-19" (OLIVEIRA, 2020, p. 389), revelando uma mudança de padrão na forma de interferência do STF no controle de constitucionalidade dos atos do presidente (Ibidem, p. 392).

Ao analisar 85 ações de controle de constitucionalidade, incluindo, além de ADIs, ADPFs e ADOs, interpostas até final de maio, a autora sugere que o STF tinha conseguido, até então, impor limites à política negacionista do presidente. $\mathrm{O}$ trabalho descreve o cenário dessas ações, que se revela muito similar ao descrito por nossa pesquisa: um terço das ações questionando normas federais que limitam direitos sociais e trabalhistas, normas que regulam economia de mercado e normas federais sobre direitos civis. A pesquisa corrobora nossos achados quanto à restrição e aos limites trazidos pelas medidas provisórias editadas no contexto da pandemia.

O estudo também chama atenção para que a maioria das decisões relativas a normas do Executivo federal possa contar com respaldo do colegiado, reduzindo, assim, o padrão de decisões monocráticas, o que também foi confirmado pela análise das ações desta pesquisa, cujo universo temporal foi ampliado em relação ao trabalho da autora. 
Recorrendo ao conceito de deserção estratégica, cunhado por Helmke (2005) para descrever situações nas quais a perda de poder do governo a Suprema Corte tenderia a decidir mais desfavoravelmente a ele, em uma estratégia de sobrevivência, Oliveira (2020, p. 396) deposita esperança na capacidade do tribunal de fazer frente às práticas autoritárias do bolsonarismo.

Em outro trabalho sobre judicialização de atos administrativos para lidar com a pandemia, Figueiredo e colaboradores (2020) investigaram ações de direito administrativo compiladas pelo Painel de Ações Covid-19, disponíveis no site do STF até final de maio. Os autores distribuíram as ações em categorias relacionadas com: medidas restritivas, informação, orçamento, accountability de servidores públicos, questões relativas à seleção e ganhos extras de funcionários públicos no contexto da pandemia, procedimentos e saúde. Dessas categorias, o maior número de ações residia na discussão das medidas restritivas (34\%) e de orçamento (34\%), seguidas de procedimentos (14\%) e informação (8\%).

Os autores apontaram, a partir dessas ações, a complexidade e o incremento do cenário da judicialização da pandemia, apostando que esta seguiria um padrão linear de crescimento. O estudo de Figueiredo e colaboradores (2020) demonstrou a grande heterogeneidade das medidas de mitigação adotadas e a resistência dos setores de atividade econômica, reforçada pelo impacto da falta de coordenação do governo federal, mas considerou que tal cenário não seria de todo novidade, uma vez que o próprio desenho do SUS estaria assentado em um conflito constante entre uma política de bases constitucionais e a autonomia das unidades federativas, com ciclos de maior centralização e descentralização, cujas disputas teriam se intensificado na pandemia, chamando o Judiciário a exercer o papel de árbitro.

Se Figueiredo e colaboradores (2020) apostaram no crescimento das ações ao longo do período, dado o grande número de processos relacionados a medidas restritivas, orçamento e saúde chegando ao Judiciário nos primeiros meses da pandemia, a nossa pesquisa permite demonstrar o oposto, ao menos no que se refere ao controle 
de constitucionalidade: o grande número de ações interpostas nos primeiros meses não foi reproduzido ao longo do período, com uma queda a partir de junho, coincidindo com as dificuldades de manutenção das medidas restritivas em estados e municípios, que acabaram optando por flexibilizações que resultaram na diminuição dos conflitos tanto entre União e entes quanto entre setores da economia e governos locais. A possibilidade de vacinação e o atraso com que o governo federal vem tratando da questão ocasionaram um novo conjunto de ações, muitas aguardando julgamento - ainda que algumas já estejam com julgamento em curso ou com sentenças procedentes em parte.

Outro trabalho sobre o comportamento da Corte durante a pandemia é o de Gomes e colaboradores (2020), que analisaram a decisão colegiada na ADI n. 6341 (relativa à MP n. 926/2020) acerca da questão federativa envolvida nos critérios de isolamento social adotados por estados e municípios. Os autores concluem que houve ali uma "mudança de trajetória" no padrão de julgamento de questões federativas. Como consequência, afirmam que:

[...] tal postura da maioria da Corte alterou temporariamente (e na circunstância da pandemia causada pelo Covid-19) a trajetória de soluções para os conflitos federativos, especificamente quanto à matéria (políticas públicas de saúde). (GOMES et al., 2020, p. 214).

Partindo dos achados desses trabalhos, acreditamos ser possível analisar ainda a trajetória de julgamento e as mudanças nos padrões de judicialização da pandemia ao longo dos meses, bem como explorar os conflitos federativos e o modo de o STF lidar com eles. 
Ainda é cedo para apontar tendências, mas os dados indicam o comportamento ativo e colegiado ${ }^{10}$ do STF, limitando os efeitos autoritários do presidente da República e as suas medidas provisórias. O efeito de contenção foi, sem dúvida, importante, uma vez que as liminares tolhendo as MPs parecem ter desencorajado o presidente a levá-las ao Congresso para conversão em lei.

Sobre as MPs, Ribeiro e Muniz (2020) demonstraram que o STF vem ampliando o seu poder ao decidir questões relacionadas ao processo legislativo e ao trâmite dessas medidas desde os anos 1990, uma vez que disputas interpretativas são levadas ao tribunal, que, por sua vez, formaliza ou veta a interpretação correspondente. Apesar de a interferência do STF sobre MPs se justificar pela pandemia, segundo os autores esse comportamento guarda

grande semelhança com padrões corriqueiros de alterações nas regras de tramitação de MP, incluindo o papel decisivo do STF - muitas vezes por decisões individuais - na formalização de (re)interpretações das regras feitas pelo Congresso e pelo Executivo. (RIBEIRO; MUNIZ, 2020, s. p.).

Buscando verificar o impacto imediato da atuação do STF, apesar da limitação metodológica da análise e na forma de apreender a judicialização restrita à análise de ADIs (RIBEIRO; ARGUELHES, 2019), é possível confirmar o efeito do tribunal como veto point (TAYLOR, 2008), impedindo a implementação das medidas provisórias que claramente extrapolam os limites constitucionais, como os casos das MPs n. 927, 928, 954, 966. Contestam-se mais normas federais (MPs) e não normas estaduais, como no período anterior.

10 Importante salientar que embora a atuação do STF seja marcada por decisões monocráticas, bastante céleres, na pandemia as decisões céleres vêm do próprio plenário, que referendam decisões monocráticas. Isso foi resultado da alteração, em $1^{\circ}$ de julho de 2020, da competência originária de julgamento de tutelas de urgência, segundo o Regimento Interno do STF, que prevê em seu art. 50 que "compete ao Plenário processar e julgar originariamente: XII - apreciar, ad referendum, decisão do relator sobre pedido de tutela de urgência, quando o objeto de questionamento for ato do Presidente da República, do Presidente da Câmara dos Deputados, do Presidente do Senado Federal e do Presidente do Supremo Tribunal Federal. (Incluído pela Emenda Regimental n. 54, de 10 de julho de 2020).. O STF das "onze ilhas" parece dar lugar a um tribunal de decisões colegiadas. 
A concessão rápida de liminares contrárias às medidas, dissuadindo o envio ao Congresso Nacional, resultou em clara restrição aos anseios do presidente da República.

O papel de limitador do STF parece se atenuar nas questões relativas a emprego e renda (MP n. 936), na Lei do FGTS, nas alíquotas de contribuições de serviços sociais (MP n. 932), no PIS-PASEP (MP n. 946). Por outro lado, o STF não apressou as discussões sobre questões relativas a leis estaduais, que continuam aguardando julgamento. A não interferência nas eleições foi incisiva, levando à improcedência da ADI n. 6362.

Sendo assim, a análise da judicialização no primeiro ano da pandemia descortina a atuação do STF e parece confirmar a hipótese de ser este um tribunal capaz de fazer frente às práticas autoritárias do presidente; o STF claramente se contrapôs às medidas do presidente, muito mais do que a literatura sobre judicialização da política retratou no passado, sobretudo em questões relativas ao combate à pandemia.

Em relação aos autores das ações, estas se comportaram como a judicialização da política nos anos FHC, promovida por partidos de oposição ${ }^{11}$ contra atos do Executivo federal.

Por fim, em relação ao comportamento dos ministros, em uma confusão que vai da judicialização da política à judicialização das políticas públicas, o embate não é necessariamente político, mas sim demonstra a discordância do tribunal em relação à política pública defendida por Bolsonaro no combate à Covid-19. Os ministros parecem estar atentos e voltados à defesa de uma política pública clara - a do isolamento social e todas as demais medidas necessárias ao enfrentamento da pandemia; mas isso não comprova, necessariamente, a defesa de um ou outro ente federativo em um sentido político mais amplo.

A questão da judicialização dos conflitos federativos merece análise aprofundada, evitando a conclusão precipitada de que a

11 Importante mencionar que os dados analisados se referem ao período anterior à formalização da entrada do chamado "centrão" à base do governo Bolsonaro, com a eleição de Arthur Lira para a Presidência da Câmara dos Deputados. 
pandemia teria alterado a tendência centralizadora da Corte, no julgamento dos conflitos entre o presidente e os governadores. A história da judicialização da política é marcada por vitórias do Executivo federal sobre os governos estaduais (OLIVEIRA, 2009; BARBOSA, 2014; CANELLO, 2016), mas algumas decisões apontaram um comportamento oposto neste momento. Por outro lado, conforme demonstramos, as decisões favoráveis à descentralização da federação brasileira estão relacionadas às medidas necessárias ao enfrentamento da pandemia. Esta, aliás, vai ao encontro de outras decisões envolvendo questões de saúde pública, como no caso da judicialização da saúde, quando o STF também decidiu pela competência compartilhada de responsabilidade entre os níveis de governo (OLIVEIRA, 2020). Outros temas de interesse dos governos estaduais continuam aguardando julgamento. Portanto, concluímos que os dados demonstram não ser possível confirmar um claro posicionamento "pró-unidades subnacionais" da Corte. Análises de longo prazo serão importantes para verificar se tal comportamento se deve à conjuntura pandêmica ou se indica um novo padrão decisório, tendencialmente menos centralizador.

\section{Considerações finais}

As cortes brasileiras vêm envolvendo-se na crise sanitária decorrente da Covid-19 em vários momentos, incluindo a decretação de lockdowns em algumas regiões (GINSBURG; VERSTEEG, 2020; CARVALHO et al., 2020). Embora Bolsonaro tenha tentado que estados e municípios encerrassem as suas ordens de lockdown, governadores em 25 dos 27 estados mantiveram as restrições, a despeito da posição do presidente. Bolsonaro questionou a autoridade estadual e municipal para impor tais medidas, o que chegou ao Supremo Tribunal Federal, o qual reconheceu a competência conjunta da União, estados e municípios em termos de saúde pública, confirmando que poderiam impor ordens restritivas regionais e locais sem o consentimento do governo federal. A decisão do STF foi, portanto, um elemento central para o combate à pandemia nas esferas subnacionais. 
O Supremo também determinou a competência dos três níveis de governo para a realização de vacinação obrigatória, o que possibilita a adoção de medidas restritivas àqueles que não se vacinarem. Sendo a saúde pública uma responsabilidade compartilhada entre os entes federados, esta também foi assim entendida.

Por outro lado, o enfrentamento do STF ao Executivo federal parece ter-se limitado às questões de políticas públicas diretamente relacionadas à pandemia. Embora tenha sido chamado a se posicionar contra muitas MPs apresentadas pelo presidente, ele não o enfrentou em diversas outras normas que tiveram a sua constitucionalidade questionada. Todavia, como muitas ADIs ainda aguardam julgamento, a atualização futura dos dados aqui apresentados será imprescindível para compreendermos como a Corte se posicionou na pandemia, em temos diretamente a ela relacionados ou não e, sobretudo, na questão dos conflitos federativos.

O que é certo, a partir dos dados analisados, é que o Supremo Tribunal Federal se contrapôs às medidas do presidente nas questões relativas à pandemia e, nesse sentido, comportou-se de maneira distinta do que as análises sobre a judicialização da política em períodos anteriores demonstraram. Por outro lado, quanto aos atores que mobilizam o Judiciário, os autores das ações, o padrão das fases iniciais da judicialização da política se manteve, com partidos de oposição, sindicatos e entidades de classe judicializando a política contra atos do Executivo federal. A judicialização da política atual repete elementos do passado e traz novidades relacionadas ao contexto específico da pandemia. Mas o novo padrão de atuação em questões federativas pode ser conjuntural, o que nos leva a concluir que ainda é cedo para se atestar a existência de um novo padrão decisório da Corte.

\section{Agradecimentos}

As autoras agradecem as valiosas contribuições de Alan Dill e Leonardo Geliski, que montaram a base de dados e as matrizes e grafos, respectivamente. 


\section{Referências}

BARBOSA, Leon Victor de Queiroz. Guerra fiscal e o ativismo judicial negativo: mapeando o conflito federativo no Supremo Tribunal Federal. Revista Política Hoje, Recife, v. 23, n. 2, p. 43-66, 2014. CANELLO, Júlio. Judicializando a Federação? O Supremo Tribunal Federal e os atos normativos estaduais. 2016. Tese (Doutorado em Ciência Política) - Instituto de Estudos Sociais e Políticos, Universidade Estadual do Rio de Janeiro, Rio de Janeiro, 2016.

CARVALHO, Eloá Carneiro; SOUZA, Pedro Hugo Dantas de Oliveira; VARELLA, Thereza Christina Mó y Mó Loureiro; SOUZA, Norma Valéria Dantas de Oliveira; FARIAS, Sheila Nascimento Pereira de; SOARES, Samira Silva Santos. COVID-19 pandemic and the judicialization of health care: an explanatory case study. Revista Latino-Americana de Enfermagem, Ribeirão Preto, v. 28, e3354, ago. 2020.

CARVALHO, Ernani Rodrigues de. Em busca da judicialização da política no Brasil: apontamentos para uma nova abordagem.

Revista de Sociologia e Política, Curitiba, n. 23, p. 127-139, 2004. CASTRO, Marcus Faro de. O Supremo Tribunal Federal e a judicialização da política. Revista Brasileira de Ciências Sociais, São Paulo, v. 12, n. 34, p. 147-156, 1997.

COSTA, Alexandre Araújo; COSTA, Henrique Araújo. Evolução do perfil dos demandantes no controle concentrado de constitucionalidade realizado pelo STF por meio de ADIs e ADPFs. Revista de Ciências Sociais. Fortaleza, v. 49, n. 2, p. 133-179, jul./out. 2018.

COUTO, Cláudio Gonçalves; OLIVEIRA, Vanessa Elias de. Politização da Justiça: atores judiciais têm agendas próprias? Cadernos Adenauer, [Online], v. XX, n. 1, p. 139-162, 2019. FIGUEIREDO, Iara Veloso Oliveira; CASTRO, Mônica Monteiro de; SILVA, Gabriela Drummond Marques da; MIRANDA, Wanessa Debôrtoli de; JÚNIOR, Helvécio Miranda Magalhães; SOUSA, Rômulo Paes de. Judicialization of administrative measures to tackle the Covid-19 pandemic in Brazil. Revista do Serviço Público, Brasília, v. 71, n. especial, p. 189-211, set. 2020. 
GOMES, José Mário Wanderley; CARVALHO, Ernani; BARBOSA, Luís Felipe Andrade. Políticas Públicas de Saúde e Lealdade Federativa: STF Afirma Protagonismo dos Governadores no Enfrentamento à Covid-19. Revista Direito Público, vol.17, n.94, p. 193-217, 2020.

GINSBURG, Tom; VERSTEEG, Mila. The bound executive: emergency powers during the pandemic. Virginia Public Law and Legal Theory Research Papers, n. 2020-52, University of Chicago, Public Law Working Papers, n. 747, p. 1-56, July 6 2020. DOI: http://dx.doi.org/10.2139/ssrn.3608974. Available at: https://ssrn.com/abstract=3608974. Accessed on: April 212021. HELMKE, Gretchen. Courts under constraints: judges, generals, and presidents in Argentina. Cambridge: Cambridge University Press, 2005.

LIMA, Flávia Danielle Santiago; GOMES NETO, José Mario Wanderley. Aparelhamento da Corte? Uma análise atitudinal da relação entre indicação partidária e comportamento decisório no Supremo Tribunal Federal (STF). Revista Direito e Justiça Reflexões Sociojurídicas, Santo Ângelo, v. 19, n. 35, p. 109-125, set./dez. 2019.

MACIEL, Débora Alves; KOERNER, Andrei. Sentidos da judicialização da política: duas análises. Lua Nova - Revista de Cultura e Política, São Paulo, n. 57, p. 113-133, 2002.

MARCHETTI, Vitor. Governança eleitoral: o modelo brasileiro de justiça eleitoral. DADOS - Revista de Ciências Sociais, Rio de Janeiro, v. 51, n. 4, p. 865-893, 2008.

MARCHETTI, Vitor; CORTEZ, Rafael. A judicialização da competição política: o TSE e as coligações eleitorais. Opinião Pública, Campinas, v. 15, n. 2, p. 422-450, 2009.

OLIVEIRA, Fabiana Luci de. Agenda suprema: interesses em disputa no controle de constitucionalidade das leis no Brasil. Tempo Social, São Paulo, v. 28, n. 1, p. 105-133, 2016.

OLIVEIRA, Fabiana Luci de. Judicialização da política em tempos de pandemia. Contemporânea, São Carlos, v. 10, n. 1, p. 389-398, jan.-abr. 2020. 
OLIVEIRA, Fabiana Luci de. Processo decisório no Supremo Tribunal Federal: coalizões e "panelinhas". Revista de Sociologia e Política, Curitiba, v. 20, n. 44, p. 139-153, 2012.

OLIVEIRA, Vanessa Elias de. Apresentação. In: OLIVEIRA, Vanessa Elias de. Judicialização de políticas públicas no Brasil. Rio de Janeiro: Editora Fiocruz, 2019. p. 16-39.

OLIVEIRA, Vanessa Elias de. Judiciário e privatizações no Brasil: existe uma judicialização da política? DADOS - Revista de Ciências Sociais, Rio de Janeiro, v. 48, n. 3, p. 1-29, 2005.

OLIVEIRA, Vanessa Elias de. Poder Judiciário: árbitro dos conflitos constitucionais entre Estados e União. Lua Nova - Revista de Cultura e Política, São Paulo, n. 78, p. 223-250, 2009.

OLIVEIRA, Vanessa Elias de; CARVALHO, Ernani. A judicialização da política: um tema em aberto. Revista Política Hoje, v.1, n.15, 2006.

RIBEIRO, Leandro Molhano; ARGUELHES, Diego Werneck. Contextos da judicialização da política: novos elementos para um mapa teórico. Revista Direito GV, v.15, n.2, p. 1-21, 2019.

RIBEIRO, Leandro Molhano; MUNIZ, Mariana Novotny. Moraes e o rito das Medidas Provisórias: mais poder para o Supremo? Jota, São Paulo, 7 abr. 2020. Disponível em: https://www.jota. info/stf/supra/moraes-e-o-rito-das-medidas-provisorias-maispoder-para-o-supremo-07042020. Acesso em: 21 abr. 2021.

SILVA, Jeferson Mariano. Mapeando o Supremo: as posições dos ministros do STF na jurisdição constitucional (2012-2017). Novos Estudos CEBRAP, São Paulo, v. 37, n. 1, p. 35-54, 2018. TAYLOR, Matthew M. Judging policy: courts and policy reform in democratic Brazil. Stanford: Stanford University Press, 2008.

TAYLOR, Matthew M.; DA ROS, Luciano. Os partidos dentro e fora do poder: a judicialização como resultado contingente da estratégia política. Dados - Revista de Ciências Sociais, Rio de Janeiro, v. 51, n. 4, p. 825-864, 2008.

VIANNA, Luiz Werneck; BURGOS, Marcelo Baumann; SALLES, Paula Martins. Dezessete anos de judicialização da política. Tempo Social, São Paulo, v. 19, n. 2, p. 39-85, 2007. 


\section{VIANNA, Luiz Werneck; CARVALHO, Maria Alice Resende de; MELO, Manuel Palacios Cunha; BURGOS, Marcelo Baumann. A judicialização da política e das relações sociais no Brasil. Rio de Janeiro: Revan, 1999.}

\section{Anexos}

Quadro 1 - Medidas provisórias atacadas em ADIs de março a novembro de $2020^{12}$

\begin{tabular}{|c|c|c|}
\hline MP questionada & Andamento em março 2021 & ADls \\
\hline $\begin{array}{l}\text { MP n. } 946 \\
\text { Extingue o Fundo PIS-Pasep, cujos ativos e passivos fi- } \\
\text { cam transferidos, na mesma data, a0 FGTS. }\end{array}$ & $\begin{array}{l}\text { Liminar indeferida em mono- } \\
\text { crática, aguarda julgamento }\end{array}$ & 6379,6416 \\
\hline $\begin{array}{l}\text { MPn. } 926 \\
\text { Altera a Lei }{ }^{0} 13.979 \text {, de 6/2/2020, sobre as me- } \\
\text { didas para enfrentamento da pandemia. }\end{array}$ & $\begin{array}{l}\text { Liminar deferida em plenário, } \\
\text { aguarda sentença }\end{array}$ & $6343,6344,6346$ \\
\hline $\begin{array}{l}\text { MPn. } 927 \\
\text { Medidas trabalhistas que poderão ser adotadas pe- } \\
\text { los empregadores para preservação do emprego e da } \\
\text { renda e para enfrentamento da pandemia. }\end{array}$ & $\begin{array}{l}\text { Liminar deferida em plenário, } \\
\text { sentença transitada em julgado }\end{array}$ & $\begin{array}{l}6342,6348,6349,6352, \\
6354,6375,6377,6380\end{array}$ \\
\hline $\begin{array}{l}\text { MP n. } 928 \\
\text { Estabelece prioridade para os pedidos de acesso à informação relacio- } \\
\text { nados ao enfrentamento da emergência de saúde pública. Suspende, } \\
\text { nas hipóteses estabelecidas, os prazos de resposta a pedidos de acesso } \\
\text { à informação nos órgãos ou nas entidades da administração pública. }\end{array}$ & $\begin{array}{l}\text { Liminar deferida em plenário, } \\
\text { sentença transitada em julgado }\end{array}$ & $6347,6351,6353$ \\
\hline $\begin{array}{l}\text { MP n. } 932 \\
\text { Promove a redução pela metade das alíquotas das contribuições } \\
\text { obrigatórias dos empregadores aos serviços sociais autônomos. } \\
\text { Prevê que as medidas de redução de jornada de trabalho e de } \\
\text { salário ou de suspensão temporária de contrato de trabalho } \\
\text { poderão ser celebradas por meio de negociação coletiva. }\end{array}$ & $\begin{array}{l}\text { Liminar julgada prejudicada em } \\
\text { monocrática, aguarda julgamento }\end{array}$ & 6373,6383 \\
\hline $\begin{array}{l}\text { MP n. } 936 \\
\text { Institui o Programa Emergencial de Manutenção do Empre- } \\
\text { go e da Renda, com aplicação durante a pandemia. }\end{array}$ & $\begin{array}{l}\text { Liminar deferida não referendada } \\
\text { em plenário, aguarda sentença }\end{array}$ & 6363,6370 \\
\hline $\begin{array}{c}\text { MPn. } 954 \\
\text { Dispõe sobre o compartilhamento de dados por empresas } \\
\text { de telecomunicações com o IBGE durante a pandemia. }\end{array}$ & $\begin{array}{l}\text { Liminar deferida em } \\
\text { plenário, processo extinto e } \\
\text { transitado em julgado }\end{array}$ & $\begin{array}{c}6387,6388,6389 \\
6390,6393\end{array}$ \\
\hline
\end{tabular}

12 Verificação do andamento das ADIs foi até março de 2021. 


\section{MPn. 945}

Dispõe sobre: a) medidas especiais em resposta à pandemia decorrente da covid-19 com o objetivo de garantir a preservação das atividades portuárias, consideradas essenciais; $\mathrm{eb}$ ) a

cessão de uso especial de pátios sob administraçãa militar.

\section{MPn. 966}

Dispõe que os agentes públicos somente poderão ser responsabilizados nas esferas civil e administrativa se agirem ou se omitirem com dolo ou erro grosseiro pela prática de atos relacionados com as medidas de: a) enfrentamento da emer-

Liminar deferida em parte em plenário, aguarda sentença
$6421,6422,6424,6425$, $6427,6428,6431$

gência de saúde pública decorrente da covid-19; eb) combate aos efeitos econômicos e sociais decorrentes da pandemia.

\section{MPn. 979}

Dispõe sobre a designação de dirigentes pro tempore para as instituições federais de ensino durante a pandemia.
Processo extinto transitado em julgado (Senado devolveu a MPe

Bolsonaro a revogou)
6458,6460

Fonte: https://www.congressonacional.leg.br/materias/medidas-provisorias. Acesso em: 6 jul. 2020.

\section{Quadro 2 - Normas federais atacadas em ADIs de março a novembro de $2020^{13}$}

\begin{tabular}{|c|c|c|c|}
\hline Norma & Conteúdo & $\begin{array}{l}\text { Andamento em } \\
\text { março } 2021\end{array}$ & ADls \\
\hline $\begin{array}{l}\text { Lei de Responsabilidade Fiscal } \\
\text { (Lei Complementarn. 101/2000) } \\
\text { e da Lei de Diretrizes Orçamen- } \\
\text { tárias (Lei n. 13.898/2019). }\end{array}$ & Responsabilidade na gestão fiscal & $\begin{array}{c}\text { Sentença } \\
\text { improcedente }\end{array}$ & $\begin{array}{c}6357 \text { (liminar deferida), } \\
6394 \text { (improcedente), } \\
6442 \text { (improcedente), } \\
6444 \text { (extinta) }\end{array}$ \\
\hline $\begin{array}{l}\text { Lei das Eleições (Lein. 9.504/1997), } \\
\text { da Lei das Inelegibilidades (Lei } \\
\text { Complementar n. 64/1990) e } \\
\text { das Resoluções n. 23.606/2019e } \\
\text { 23.609/2019 do TSE, que dispõem } \\
\text { sobre o calendário para as Eleições } \\
\text { de } 2020 \text { e o registro de candidatura. }\end{array}$ & $\begin{array}{l}\text { Calendário eleitoral e domićílio elei- } \\
\text { toral, registro de candidaturas }\end{array}$ & $\begin{array}{l}\text { Liminar indeferida } \\
\text { em plenário, sentença } \\
\text { improcedente tran- } \\
\text { sitada em julgado }\end{array}$ & 6359 \\
\hline Lein. 13.979/2020 & $\begin{array}{l}\text { Requisição administrativa de bens e serviços } \\
\text { por gestores locais no combate ao coronavírus } \\
\text { sem o controle da União e sem o esgotamento } \\
\text { de alternativas menos gravosas disponíveis; } \\
\text { determinação de realização compulsória de } \\
\text { vacinaçâo e outras medidas profiláticas }\end{array}$ & $\begin{array}{l}\text { Liminar não julgada, } \\
\text { com sentença impro- } \\
\text { cedente transitada } \\
\text { em julgado; ação } \\
\text { procedente em parte }\end{array}$ & $6362,6586,6587$ \\
\hline
\end{tabular}

13 A verificação do andamento das ADls foi até março de 2021. 


\begin{tabular}{|c|c|c|c|}
\hline Lei do FGTS (Lei n. 8.036/1990) & $\begin{array}{l}\text { Liberação em caso de município } \\
\text { em situação de emergência ou es- } \\
\text { tado de calamidade pública }\end{array}$ & $\begin{array}{l}\text { Liminar indeferida } \\
\text { em monocrática, } \\
\text { aguarda julgamento }\end{array}$ & 6371 \\
\hline Lein. 10316 & $\begin{array}{l}\text { Medidas de proteção so- } \\
\text { cial - auxilio emergencial }\end{array}$ & Aguarda julgamento & 6398 \\
\hline $\begin{array}{l}\text { Lein. 13.982/2020 e De- } \\
\text { creton. 10.316/2020 }\end{array}$ & BPC - auxílio emergencial & Aguarda julgamento & 6409 \\
\hline $\begin{array}{l}\text { Emenda Constitucional n. } \\
\text { 106/2020 - "Emenda do } \\
\text { Orçamento de Guerra" }\end{array}$ & $\begin{array}{l}\text { Regime extraordinário fiscal, fi- } \\
\text { nanceiro e contratações }\end{array}$ & Aguarda julgamento & 6417 \\
\hline LCn. 173/2020 & $\begin{array}{l}\text { Programa Federativo de Enfrentamento } \\
\text { à Covid-19; proibição de execução de } \\
\text { dívidas de estados e DF por parte da União; } \\
\text { ajuda financeira a estados, municípios e } \\
\text { Distrito Federal para o combate aos efeitos } \\
\text { da pandemia do novo coronavírus. }\end{array}$ & $\begin{array}{l}\text { Liminar não julgada, } \\
\text { com processos } \\
\text { extintos transitados } \\
\text { em julgado }\end{array}$ & $\begin{array}{c}6444,6447,6450 \\
6456,6465,6485, \\
6525,6526,6541,6542\end{array}$ \\
\hline Resolução n. 4782/2020 Bacen & $\begin{array}{l}\text { Estabelece, por tempo determinado, em } \\
\text { função de eventuais impactos da Covid-19 } \\
\text { na economia, critérios temporários para } \\
\text { a caracterização das reestruturaçōes } \\
\text { de operaçōes de crédito, para fins de } \\
\text { gerenciamento de risco de crédito. }\end{array}$ & $\begin{array}{l}\text { Liminar não julgada, } \\
\text { negado seguimento } \\
\text { e trânsito em julgado }\end{array}$ & 6368 \\
\hline Lein. 10233/2001 & $\begin{array}{l}\text { Dispõe sobre a reestruturação dos transportes } \\
\text { aquaviário e terrestre, cria o Conselho Nacional } \\
\text { de Integração de Políticas de Transporte, a } \\
\text { Agência Nacional de Transportes Terrestres, a } \\
\text { Agência Nacional de Transportes Aquaviários } \\
\text { e o Departamento Nacional de Infra-Estrutura } \\
\text { de Transportes, e dá outras providências. }\end{array}$ & $\begin{array}{l}\text { Processo extinto, } \\
\text { ação não conhecida e } \\
\text { trânsito em julgado }\end{array}$ & 6481 \\
\hline Lein. 13116/2015 & $\begin{array}{l}\text { Estabelece normas gerais para implantação } \\
\text { e compartilhamento da infraestrutura de } \\
\text { telecomunicações e altera as Leis no } 9.472 \text {, } \\
\text { de } 16 \text { de julho de } 1997,11.934 \text {, de } 5 \text { de maio } \\
\text { de } 2009 \text {, e } 10.257 \text {, de } 10 \text { de julho de } 2001 \text {. }\end{array}$ & $\begin{array}{l}\text { Sentença } \\
\text { improcedente }\end{array}$ & 6382,6482 \\
\hline $\begin{array}{l}\text { ADCT, EC n. 53/2006, Lei } \\
\text { n. 9394/1996, LDB Lei n. } \\
\text { 11494/1997, Fundeb }\end{array}$ & $\begin{array}{l}\text { "Regulamenta o Fundo de Manutenção } \\
\text { e Desenvolvimento da Educação Básica e } \\
\text { de Valorização da Educação - FUNDEB" }\end{array}$ & Aguarda julgamento & 6490 \\
\hline Resolução n. 320/2020 CNJ & $\begin{array}{l}\text { Alterar a Resolução CNJ no 185/2013, que } \\
\text { institui o Sistema Processo Judicial Eletrônico } \\
\text { - PJe como sistema de processamento de } \\
\text { informações e prática de atos processuais } \\
\text { e estabelece os parâmetros para sua } \\
\text { implementação e funcionamento. }\end{array}$ & Aguarda julgamento & 6527 \\
\hline
\end{tabular}


Nota Técnica n. 1556/2020

CGU e Lei n. 8112/1990
Inconstitucionalidade da NT no que se refere ao alcance e conteúdo dos arts. 116, inciso II e 117, inciso V, da Lei no 8.112/1990, visando, especialmente, promover a justa adequação destes às hipóteses de condutas irregulares de dos meios digitais de comunicação online.

Fonte: elaborado pelas autoras a partir da base de dados das ADIs sobre coronavírus.

\section{Quadro 3 - Leis estaduais atacadas em ADIs de março a novembro de $2020^{14}$}

\begin{tabular}{|c|c|c|c|}
\hline Normas estaduais & Conteúdo & $\begin{array}{l}\text { Andamento em } \\
\text { março } 2021\end{array}$ & ADls \\
\hline Lei Estadual n. 11.087/2020 & verba indenizatória, atividade controle externo TC estados & $\begin{array}{l}\text { Liminar deferida } \\
\text { em plenário, } \\
\text { aguarda sentença }\end{array}$ & 6376 \\
\hline $\begin{array}{l}\text { Lei Estadual n. 8.769/2020; Lei } \\
\text { Estadual n. 17.933/2020/SC; } \\
\text { Lei Estadual n. 20.187/2020/ } \\
\text { PR; Lei Estadual n. 17.933/2020; } \\
\text { Lei Estadual n. 1.389/2020; Lei } \\
\text { Estadual n. 1.399/2020; Lei } \\
\text { Estadual n. 4738/2020 R0; Lei } \\
\text { Estadual n. 5145/ 2020 AM; Lei } \\
\text { Estadual n. 5143/2020 AM }\end{array}$ & $\begin{array}{l}\text { proibiçãa de interrupção de serviços essenciais por } \\
\text { falta de pagamento; proibição de inscrição em órgãos } \\
\text { de proteção a crédito de consumidores que estejam } \\
\text { em atraso nas contas de serviços essenciais }\end{array}$ & Aguardam julgamento & $\begin{array}{l}6376,6405, \\
6406,6410, \\
6411,6432, \\
6438,6588\end{array}$ \\
\hline Lei Estadual n. 4.620/2019 & $\begin{array}{l}\text { vedação instituições financeiras celebrar } \\
\text { contratos de empréstimo com aposentados } \\
\text { e pensionistas por ligação telefônica }\end{array}$ & Aguarda julgamento & 6418 \\
\hline $\begin{array}{l}\text { Lei Estadual n. 11.259/2020; } \\
\text { Lei Estadual n. 9065/2020 PA; } \\
\text { Lei Estadual n. 8864/2020 } \\
\text { RJ; Lei n. 17208/2020 CE; Lei } \\
\text { Estadual n. 14279/2020 BA }\end{array}$ & Descontos de mensalidade - educação privada & $\begin{array}{l}\text { Ações com sentença } \\
\text { procedente ou aguar- } \\
\text { dando julgamento }\end{array}$ & $\begin{array}{c}6423,6435 \\
64456448 \\
6575\end{array}$ \\
\hline $\begin{array}{l}\text { Lei Estadual n. 8811/2020 Rj; Lei } \\
\text { Estadual n. 11735/2020 PB; Lei } \\
\text { Estadual n. 11281/2020 MA; Lei } \\
\text { Estadual n. 11716/2020 PB; Lei } \\
\text { Estadual n. 11756/2020 PB; }\end{array}$ & $\begin{array}{l}\text { Vedação, suspensão e cancelamento de planos de } \\
\text { saúde por falta de pagamento; proibição de operadoras } \\
\text { de planos de saúde por recusarem a prestação de } \\
\text { serviços a pessoas suspeitas ou contaminadas pela } \\
\text { Covid-19 em razão de prazo de carência contratual }\end{array}$ & Aguardam julgamento & $\begin{array}{l}6441,6443, \\
6486,6491, \\
6493,6494 \\
6538\end{array}$ \\
\hline Lei Estadual n. 10276/2015 MT & Remuneração procuradores legislativos MT & $\begin{array}{l}\text { Liminar não julgada e } \\
\text { sentença procedente } \\
\text { em parte }\end{array}$ & 6436 \\
\hline
\end{tabular}

14 A verificação do andamento das ADls foi até março de 2021. 


\begin{tabular}{|c|c|c|c|}
\hline Lei Estadual n. 9782/2012 MT & $\begin{array}{l}\text { Quadro de pessoal e planos de carreira ser- } \\
\text { vidores da Procuradoria de Justiça MT }\end{array}$ & Aguarda julgamento & 6414 \\
\hline $\begin{array}{l}\text { Lei Estadual n. 8842/2020 RJ; } \\
\text { Lei Estadual n. 11274/2020 MA; } \\
\text { Lei Estadual n. 11699/2020 PB }\end{array}$ & Suspensão de pagamento de empréstimos consignados & $\begin{array}{l}\text { Ações com liminar de- } \\
\text { ferida em plenário e/ou } \\
\text { sentença procedente }\end{array}$ & $\begin{array}{l}6451,6475, \\
6495\end{array}$ \\
\hline Lei Estadual n. 11157/2020 MT & Renda mínima emergencial para professores estaduais & Aguarda julgamento & 6488 \\
\hline Lei Estadual n. 10733/2020 RN & $\begin{array}{l}\text { Critérios temporários para a execução da campa- } \\
\text { nha de incentivo a emissão de documentos fiscais } \\
\text { por estabelecimentos contribuintes ICMS }\end{array}$ & $\begin{array}{l}\text { Liminar deferida em } \\
\text { plenário e sentença } \\
\text { procedente }\end{array}$ & 6484 \\
\hline Lei Estadual n. 13729/2006CE & Estatuto dos Militares estaduais do Ceará & $\begin{array}{l}\text { Liminar julgada } \\
\text { prejudicada em } \\
\text { monocrática e sentença } \\
\text { transitada em julgado }\end{array}$ & 6374 \\
\hline Lei Estadual n. 8932/2020 RJ & $\begin{array}{l}\text { Obrigatoriedade dos supermercados, hipermercados e/ } \\
\text { ou congêneres oferecerem o serviço de empacotador }\end{array}$ & Aguarda julgamento & 6498 \\
\hline ECn. 077/2020SC & $\begin{array}{l}\text { Estabelecimento de prazo de } 72 \text { horas para respostas a } \\
\text { pedidos de informação encaminhados pela AL relativos } \\
\text { ao acompanhamento da situação fiscal e execução } \\
\text { orçamentária e financeira de medidas relacionadas } \\
\text { ao enfrentamento da pandemia da Covid-19 }\end{array}$ & Aguarda julgamento & 6498,6530 \\
\hline LCn. 425/2020 PE & $\begin{array}{l}\text { Procedimentos para contratações destinadas ao } \\
\text { fornecimento de bens, prestação de serviços, } \\
\text { locação de bens e execução de obras neces- } \\
\text { sárias ao enfrentamento do coronavírus }\end{array}$ & Aguarda julgamento & 6464 \\
\hline LCn. 234/2002ES & Código de organização judiciária do Espírito Santo & Aguarda julgamento & 6439 \\
\hline RES n. 003/2017 AM & $\begin{array}{l}\text { Programa de Residência Jurídica no âmbito da } \\
\text { Defensoria Pública do Estado do Amazonas. }\end{array}$ & $\begin{array}{l}\text { Julgada prejudicada } \\
\text { em monocrática, } \\
\text { aguarda julgamento }\end{array}$ & 6478 \\
\hline Decreto Legislativo n. 054/2019 MT & Subsídios deputados estaduais & Aguarda julgamento & 6437 \\
\hline
\end{tabular}

Fonte: elaborado pelas autoras a partir da base de dados das ADIs sobre coronavírus.

\section{Resumo}

O presente artigo discute a judicialização da política no enfrentamento à Covid-19 no Brasil. Analisamos se o padrão de judicialização da política verificado na pandemia é novo ou, ao contrário, repete aquele verificado nos anos 1990 e no início dos anos 2000, caracterizado pelo uso político do Judiciário pelos partidos de oposição e pelo favorecimento da centralização federativa. Os resultados demonstram que se mantém o padrão anterior, em termos de quem mobiliza o Judiciário, mas com 
resultados distintos em termos do conflito federativo: nos casos de controle de constitucionalidade de atos relacionados ao enfrentamento da pandemia, o presidente mais perde do que ganha no Supremo Tribunal Federal (STF). No entanto, nos casos não relacionados às medidas sanitárias de combate à Covid-19, ainda não é possível afirmar a existência de um novo padrão decisório.

Palavras-chave: Judicialização da política. Covid-19. Supremo Tribunal Federal. Controle de constitucionalidade. Conflitos federativos.

\section{Abstract}

This article discusses the judicialization of politics in the fight against Covid-19 in Brazil. We analyzed whether the pattern of judicialization of politics verified in the pandemic is new or, on the contrary, repeats that verified in the 90 s and early 00 s, characterized by the political use of the Judiciary by opposition parties and by favoring federative centralization. The results demonstrate that the previous pattern remains, in terms of who mobilizes the Judiciary, but with different results in terms of federative conflict: in cases of judicial review of acts related to confronting the pandemic, the president loses more than he gains in the STF. However, in cases unrelated to the sanitary measures to combat Covid-19, it is not yet possible to affirm the existence of a new decision-making pattern.

Keywords: Judicialization of politics. Covid-19. Brazilian Supreme Court. Judicial review. Federative conflicts.

Recebido em 28 de dezembro de 2020

Aceito em 16 de abril de 2021 